\title{
Thromboembolic complications after an ankle joint open fracture in a patient with a history of deep vein thrombosis in the lower limbs
}

\author{
Tomasz Stankowski ${ }^{1}$, Sleiman Sebastian Aboul-Hassan ${ }^{1}$, Piotr Stępiński ${ }^{1}$, Anna Szymańska ${ }^{1}$, \\ Jakub Marczak ${ }^{2}$, Romuald Cichoń ${ }^{1}$ \\ ${ }^{1}$ Department of Cardiac Surgery, Medinet Heart Center Ltd, Wrocław, Poland \\ ${ }^{2}$ Department of Cardiac Surgery, Wroclaw Medical University, Wrocław, Poland \\ Kardiochirurgia i Torakochirurgia Polska 2017; 14 (1): 47-49
}

\begin{abstract}
A 55-year-old patient was admitted to the Department of Orthopedics due to an open fracture in the right ankle joint. On the seventh day of hospitalization the patient experienced a transient ischemic attack. During the next day, dyspnea, chest pain and a 'rider' type pulmonary embolism in the pulmonary trunk occluding both pulmonary arteries and its branches were diagnosed. The patient was transferred to the Department of Cardiac Surgery. He underwent pulmonary embolectomy for massive pulmonary, right and left atrial embolism, and left ventricular embolism. ASD II was closed during this procedure. Ultrasonography with Doppler was performed 6 days after the surgery and revealed deep vein thrombosis, so the patient was transferred to the Department of Vascular Surgery for temporary inferior vena cava filter placement at the time of orthopedic surgery. The next day after implantation of the filter, the lower limb was operated on, and 14 days after orthopedic surgery, the vena cava filter was removed.
\end{abstract}

Key words: pulmonary embolectomy, deep venous thrombosis.

\section{Introduction}

Venous thromboembolism (VTE) is treated as an interdisciplinary disease due to the fact that it may cause disabling or even life-threatening complications. It includes both deep vein thrombosis (DVT) and pulmonary embolism (PE). The pathogenesis of thrombus formation inside the vessels was described by Rudolf Virchow in 1856; it is now called Virchow's triad, and it includes endothelial injury, abnormal blood flow and hypercoagulability. The risk factors of such thrombus formation in the vessels are age above 40, injuries, fractures, immobilization, tumors, obesity, thrombocytosis and varicose veins. The most severe complication of deep vein thrombosis is pulmonary embolism, which could lead to death if the patients are not treated emergently in specialized units [1].

\section{Streszczenie}

Mężczyzna 55-letni został przyjęty na oddział ortopedyczno-urazowy z powodu złamania prawego stawu skokowego. W siódmym dniu hospitalizacji wystąpiła u pacjenta zatorowość płucna wysokiego ryzyka (typu ,jeździec”). Następnego dnia stwierdzono przemijający atak niedokrwienny. Pacjenta przekazano w trybie ostrodyżurowym na oddział kardiochirurgii i przeprowadzono zabieg embolektomii zatoru tętnicy płucnej, prawego i lewego przedsionka oraz lewej komory. Usunięto materiał zatorowy z tętnicy płucnej wraz z jej odgałęzieniami oraz z jam lewego serca, zwłaszcza z przedniego płatka zastawki mitralnej, wraz z zamknięciem ubytku w przegrodzie międzyprzedsionkowej typu ASD II. W badaniu dopplerowskim żył kończyn dolnych wykonanym 6 dni po zabiegu stwierdzono cechy zakrzepicy żył głębokich i przekazano chorego na oddział chirurgii naczyniowej w celu wszczepienia czasowo filtru do żyły głównej dolnej na czas zabiegu ortopedycznego. Czternaście dni po operacji stawu skokowego usunięto filtr z żyły głównej dolnej.

Słowa kluczowe: zatorowość płucna, zakrzepica żył głębokich.

\section{Case report}

A 55-year-old male patient (body mass index (BMI) $30 \mathrm{~kg} /$ $\mathrm{m}^{2}$ ) with a history of previous deep vein thrombosis in the lower limbs in the year 2000 was admitted to the Department of Orthopedics due to an open fracture in the right ankle joint. Right ankle X-ray revealed distal fracture of the fibula with slightly displaced bone parts. Widened ankle joint space in its medial part and bone erosion in the distal part of the tibial bone were also observed. The patient was treated pharmacologically with acetylsalicylic acid, low molecular weight heparin, amoxicillin-clavulanate, metronidazole, ketoprofen, amikacin and metamizole. A short leg cast was applied and surgery was planned 9 days after. Two days before the planned surgery, the patient had a transient ischemic attack (TIA). A computed tomography (CT) 


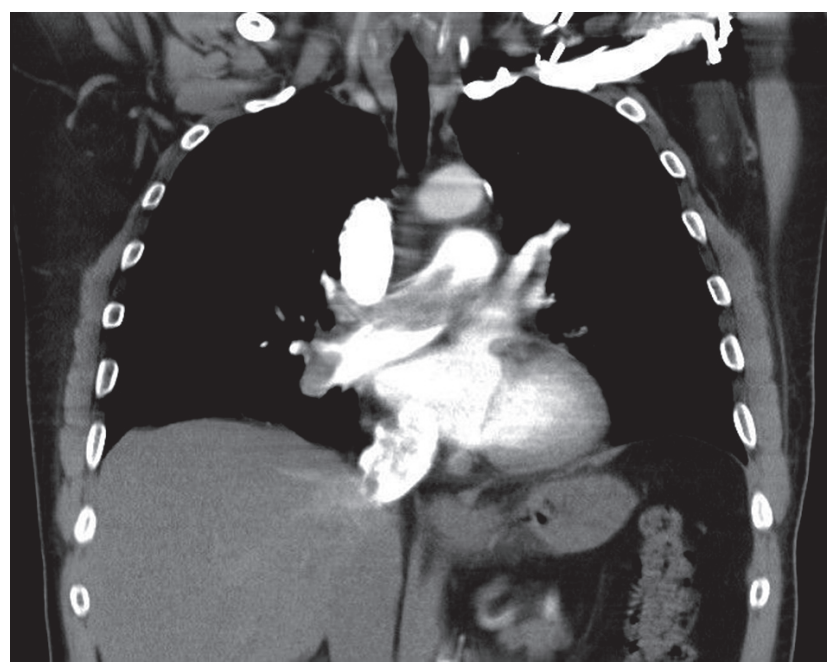

Fig. 1. Chest computed tomography. Pulmonary embolism

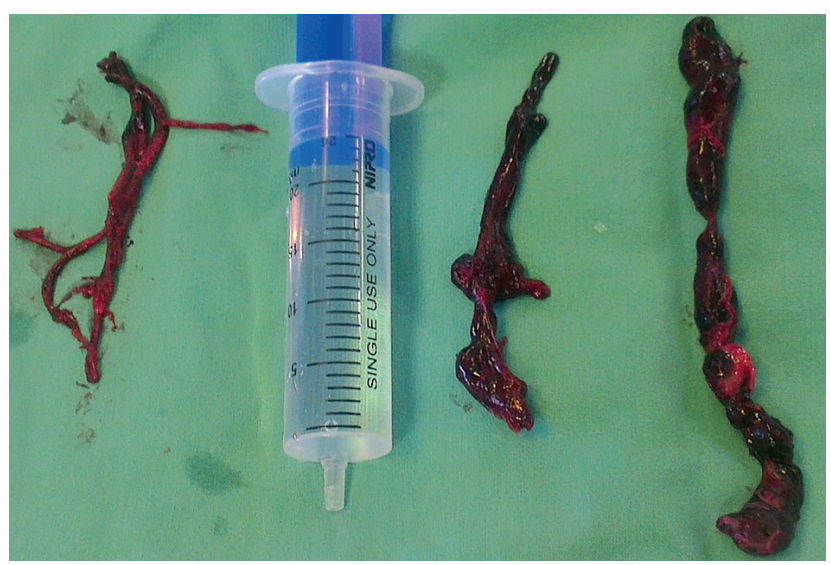

Fig. 2. Intraoperative pictures of the thrombus

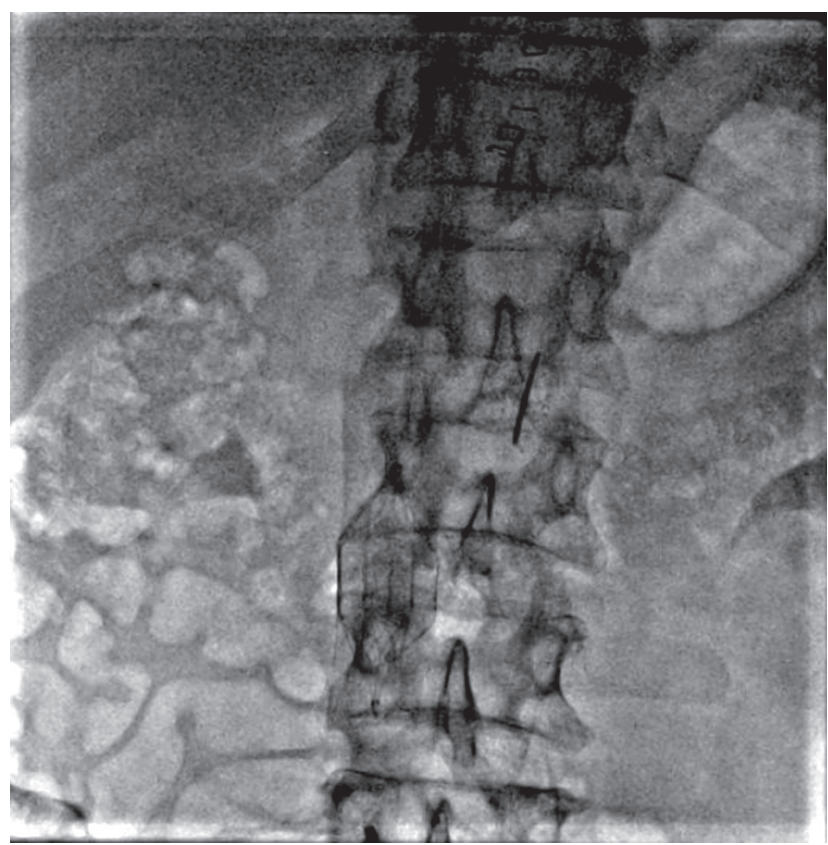

Fig. 3. Inferior vena cava filter scan performed immediately ruled out stroke. During the next day, the patient reported dyspnea with chest pain and was transferred to the Department of Cardiology. Computed tomography angiogram revealed a 'rider' type pulmonary embolism in the pulmonary trunk occluding both pulmonary arteries and their branches (Fig. 1). In the $10^{\text {th }}$ segment of the right lung atelectasis, which could be a sign of lung infarction, was observed. Advanced pulmonary emphysema with pulmonary tissue destruction especially in the upper lobes was also observed. Echocardiography revealed a wide thrombus appearing as a snake-like structure in the right atrium near the tricuspid valve protruding through the patent foramen ovale to the left atrium. Thrombotic oppositions were also observed attached to the anterior leaflet of the mitral valve and moving further towards the left ventricle. The patient was transferred to the department of cardiac surgery for further surgical treatment. On admission, the patient suffered from dyspnea at rest and severe hypoxia with features of heart failure (NYHA IV). The patient underwent emergent surgical embolectomy for massive pulmonary embolism, involving both atria and the left ventricle. Thrombotic material from the left ventricle was evacuated through the aortic valve (Fig. 2). Atrial septal defect type II was closed during the surgery. Postoperatively the patient recovered uneventfully, but the postoperative laboratory tests revealed a high troponin I level: 14.932 $\mu \mathrm{g} / \mathrm{l}$ (norm: 0.012-0.4 $\mu \mathrm{g} / \mathrm{l}$ ), D-dimer 3.21 $\mu \mathrm{g} / \mathrm{ml}$ (norm: $<0.5 \mu \mathrm{g} / \mathrm{ml}$ ), brain natriuretic peptide (BNP) $453.9 \mathrm{pg} / \mathrm{ml}$ (norm: $0.4-30 \mathrm{pg} / \mathrm{ml}$ ). Lower limb venous Doppler ultrasonography was performed 6 days after the surgery and revealed again DVT, involving the superficial femoral vein, popliteal vein and intramuscular gastrocnemius veins. The patient was transferred to the Department of Vascular Surgery for temporary inferior vena cava filter placement for the time of orthopedic treatment (Fig. 3). The next day after implantation of the filter, the lower limb was operated on. Surgery was performed, where the fixation of the medial malleolus fracture was treated with a bundle of K-wires, and the fixation of the lateral malleolus fracture was treated with lateral plate fixation and stainless screws + one screw into the syndesmosis with K-wire. Fourteen days after orthopedic surgery, the vena cava filter was removed (Fig. 4). Two years following the surgery, the patient had experienced no adverse events.

\section{Discussion}

Venous thromboembolism appears in the form of DVT or PE. Pulmonary embolism occurs mainly in patients with deep vein thrombosis. The risk factors for the development of VTE can be divided into strong, moderate and weak. Strong risk factors include fractures (especially in the pelvis and lower limb), hip or knee replacement surgery, major long lasting surgery, multiple traumatic injuries and spinal cord injuries. Moderate risk factors include congestive heart or respiratory failure, hormone replacement therapy, tumors, paralytic strokes, thrombophilia and previous thromboembolism. Weak risk factors include age, obesity, 
varicose veins, bed rest more than three days, and immobility due to sitting (long lasting car travel or air travel) [2].

In this case, our patient was 55 years old with moderate obesity $\left(\mathrm{BMI}=30 \mathrm{~kg} / \mathrm{m}^{2}\right)$ and a history of previous venous thromboembolism. One week before the pulmonary embolism incident our patient sustained a fracture in his right ankle joint and was immobilized for the next seven days. In this case, the pulmonary embolism caused enlargement of the right ventricle $(R V=3.7 \mathrm{~cm}$ ) revealed in the echocardiography, as well as a perioperative high level of BNP: $453.0 \mathrm{pg} / \mathrm{ml}$ (norm: 0.4-30 pg/ml) as a result of right ventricle dysfunction and high troponin I level: $14.932 \mu \mathrm{g} / \mathrm{l}$ (norm: $0.012-0.4 \mu \mathrm{g} / \mathrm{l}$ ) as a result of myocardial injury. The revealed diagnostic results could lead to an increase of the mortality rate by up to $15 \%$ in patients with pulmonary embolism [3, 4]. After confirmation of the pulmonary embolism, the medical staff had to decide whether to enroll the patient for thrombolytic treatment or surgical pulmonary embolectomy. Standard thrombolytic therapy used to break up clots is based on streptokinase or alteplase (recombinant tissue plasminogen activator); however, it has significant side effects especially in terms of increased risk of heavy bleeding and must therefore be used with caution. There are absolute contraindications to the use of thrombolytic therapy in patients with a history of previous hemorrhagic stroke of unknown origin, history of previous ischemic stroke in the last 6 months, tumors in the central nervous system (CNS), bleeding in the digestive tract in the last month, coagulopathy, traumatic brain injuries, brain surgery or any head trauma in the last 3 weeks. Relative contraindications to the use of thrombolytic therapy are occurrence of a TIA in the last 6 months, current anticoagulant use, pregnancy, controlled severe hypertension, active peptic ulcer, advanced liver diseases and infective endocarditis [5-8]. The patient was scheduled for surgical pulmonary embolectomy, due to the multiple open fractures in his right ankle which disqualified him from thrombolytic treatment.

\section{Conclusions}

The management of patients with many coexisting risk factors of developing pulmonary embolism is to perform adequate medical evaluation of the patient's status and to undertake a suitable type of treatment. In high-risk pulmonary embolism, surgical embolectomy is still an alternative method of treating these patients, especially when the thrombolytic therapy is ineffective or there are absolute contraindications to the use of such therapy. Patients who underwent surgical pulmonary embolectomy should be diagnosed whether the cause of this pulmonary embolism is deep vein thrombosis or any other cause. In this case, the

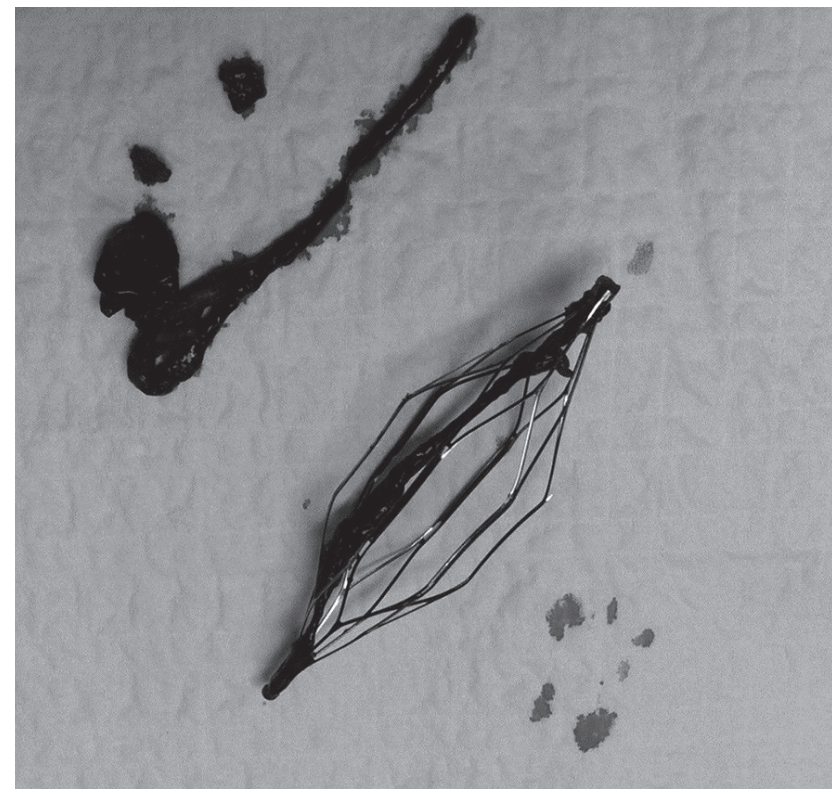

Fig. 4. Intraoperative pictures after the removal of the inferior vena cava filter. Thrombotic materials can be observed

patient had deep vein thrombosis. In such patients, temporary inferior vena cava filter placement seems to be a good option for preventing any other pulmonary embolism.

\section{Disclosure}

Authors report no conflict of interest.

\section{References}

1. Cardiac Surgery. Kirklin JW, Barratt-Boyes BG (eds.). Vol. 2. $3^{\text {rd }}$ ed. Wiley, New York 1993.

2. Anderson FA Jr, Spencer FA. Risk factors for venous thromboembolism. Circulation 2003; 107 (23 Suppl. 1): 19-116.

3. Wood KE. Major pulmonary embolism: review of a pathophysiologic approach to the golden hour of hemodynamically significant pulmonary embolism. Chest 2002; 121: 877-905.

4. Goldhaber SZ, Visani L, De Rosa M. Acute pulmonary embolism: clinical outcomes in the International Cooperative Pulmonary Embolism Registry (ICOPER). Lancet 1999; 353: 1386-1389.

5. Meyer G, Sors H, Charbonnier B, Kasper W, Bassand JP, Kerr IH, Lesaffre E, Vanhove $P$, Verstraete $M$. Effects of intravenous urokinase versus alteplase on total pulmonary resistance in acute massive pulmonary embolism: a European multicenter double-blind trial. The European Cooperative Study Group for Pulmonary Embolism. J Am Coll Cardiol 1992; 19: 239-245.

6. Sors H, Pacouret G, Azarian R, Meyer G, Charbonnier B, Simonneau G. Hemodynamic effects of bolus vs 2 -h infusion of alteplase in acute massive pulmonary embolism. A randomized controlled multicenter trial. Chest 1994; 106: 712-717.

7. Kanter DS, Mikkola KM, Patel SR, Parker JA, Goldhaber SZ. Thrombolytic therapy for pulmonary embolism. Frequency of intracranial hemorrhage and associated risk factors. Chest 1997; 111: 1241-1245.

8. Kirschner M. Ein durch die Trendelenburgsche Operation geheilter Fall von Embolie der Arteria pulmonalis. Arch Klin Chir 1924; 133: 312-359. 